\title{
Plasma Cell Myeloma Post-Transplant Lymphoproliferative Disorder
}

National Cancer Institute

\section{Source}

National Cancer Institute. Plasma Cell Myeloma Post-Transplant Lymphoproliferative

Disorder. NCl Thesaurus. Code C7242.

A lymphoproliferative disorder that develops following an org an transplantation and exhibits plasma cell myeloma features. 